\title{
Zooplankton community respiration during the JGOFS pilot study
}

\author{
Peter Martens \\ Biologische Anstalt Helgoland, Wattenmeerstation Sylt; D-W-2282 List, Federal Republic \\ of Germany
}

\begin{abstract}
From March to July 1989 (JGOFS pilot study), measurements were carried out on the oxygen uptake of natural zooplankton communities on five drifting stations (about three weeks each) in the Atlantic from $18^{\circ} \mathrm{N}$ to $72^{\circ} \mathrm{N}$ after a method of Martens (1986). The weight specific respiration rate decreased from south to north parallel to the water temperature, whereas the amount of mesozooplankton increased. No significant differences in the oxygen uptake of the zooplankton community between the five stations could be found. A rough estimate showed that less than $2 \%$ of the phytoplankton carbon was assimilated by the mesozooplankton per day. This is thought to reflect a typical spring situation. The weight specific respiration rate is influenced significantly by the water temperature and the mean length of the zooplankter.
\end{abstract}

\section{INTRODUCTION}

"The Joint Global Ocean Flux Study (JGOFS) has taken as its central mandate the tasks of determining on a global scale the processes controlling the fluxes of carbon and other biogenic elements in the ocean. The annual phytoplankton bloom offered a unique opportunity to observe some of these processes in action." (Bowles, 1991). The northeastern Atlantic became the site of the first JGOFS process study in 1989. One hundred years earlier, German scientists under the leadership of Victor Hensen undertook the first-ever large-scale study of phytoplankton in the Atlantic. So the German part of the JGOFS pilot study marked the centennial of that expedition.

A main goal of the JGOFS pilot study dealt with the formation, transformation and export of particles of biological origin within and from the euphotic zone with special focus on processes dealing with the retention of biogenic particles within the mixed layer (regenerated production). The zooplankton as second level of the marine food web can be of great importance to these processes. During food uptake intracellular phytoplankton products are released. The formation of faecal pellets changes the size distribution of the particulate matter in the water column which has an influence on the sedimentation process. Furthermore, the diurnal migrations can accelerate the transport of organic material to deeper water layers.

The aim of the investigation presented in this paper was to throw light on the subject of the oxygen uptake of the zooplankton community as a rough estimate of the physiological activity of the zooplankton at different locations in the Atlantic Ocean. 


\section{MATERIALS AND METHODS}

From March $24^{\text {th }}$ to July $9^{\text {th }}$ measurements were performed on five drifting stations (Figure 1) following a drifting buoy to analyse the oxygen uptake of the mesozooplankton community. The drifting stations were as follows:

(1) $18^{\circ} 19^{\prime} 26^{\prime \prime} \mathrm{N} / 29^{\circ} 35^{\prime} 53^{\prime \prime} \mathrm{W}$ to $18^{\circ} 48^{\prime} 25^{\prime \prime} \mathrm{N} / 30^{\circ} 40^{\prime} 55^{\prime \prime} \mathrm{W}$ from $24^{\text {th }}$ March 1989 to $7^{\text {th }}$ April 1989 with 24 experiments.

(2) $33^{\circ} 56^{\prime} 53^{\prime \prime} \mathrm{N} / 20^{\circ} 55^{\prime} 44^{\prime \prime} \mathrm{W}$ to $33^{\circ} 13^{\prime} 01^{\prime \prime} \mathrm{N} / 21^{\circ} 24^{\prime} 44^{\prime \prime} \mathrm{W}$ from $13^{\text {th }}$ April 1989 to $24^{\text {th }}$ April 1989 with 21 experiments.

(3) $46^{\circ} 30^{\prime} 43^{\prime \prime} \mathrm{N} / 19^{\circ} 03^{\prime} 14^{\prime \prime} \mathrm{W}$ to $46^{\circ} 14^{\prime} 56^{\prime \prime} \mathrm{N} / 18^{\circ} 49^{\prime} 08^{\prime \prime} \mathrm{W}$ from $7^{\text {th }}$ May 1989 to $20^{\text {th }}$ May 1989 with 26 experiments.

(4) $57^{\circ} 39^{\prime} 07^{\prime \prime} \mathrm{N} / 23^{\circ} 13^{\prime} 12^{\prime \prime} \mathrm{W}$ to $58^{\circ} 18^{\prime} 00^{\prime \prime} \mathrm{N} / 24^{\circ} 40^{\prime} 19^{\prime \prime} \mathrm{W}$ from $28^{\text {th }}$ May 1989 to $8^{\text {th }}$ June 1989 with 22 experiments.

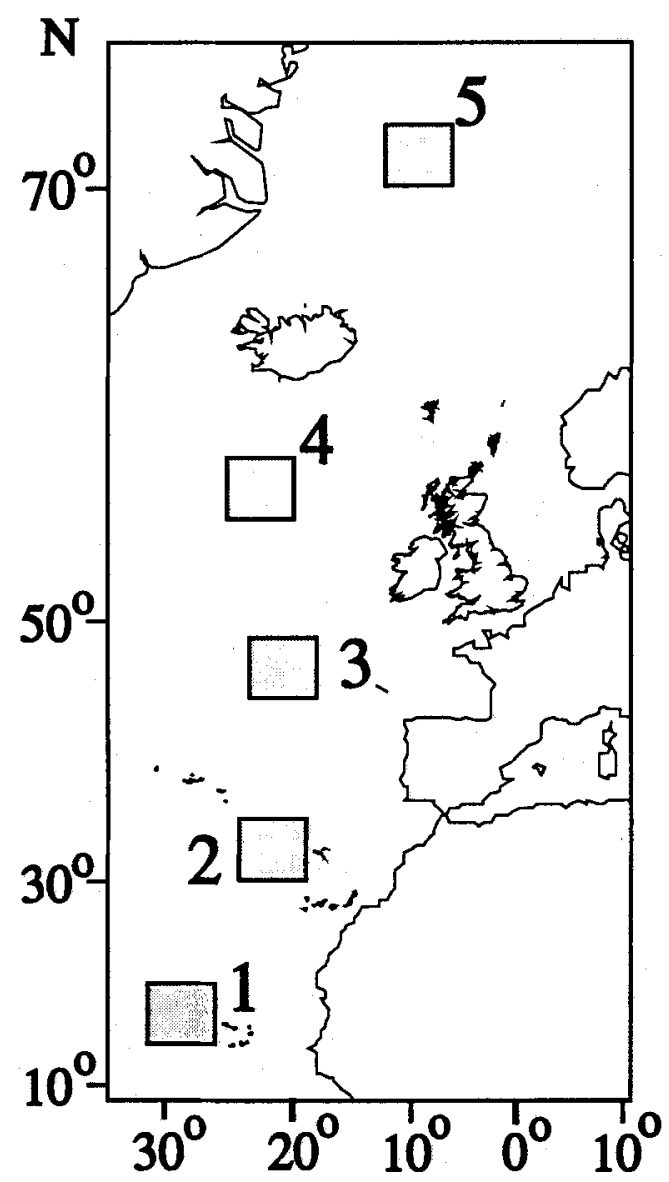

Fig. 1. Location of the five drifting areas during the JGOFS pilot study. $1: 18^{\circ} \mathrm{N} / 29^{\circ} \mathrm{W} ; 2: 33^{\circ} \mathrm{N} /$ $21^{\circ} \mathrm{W}_{;} 3: 46^{\circ} \mathrm{N} / 19^{\circ} \mathrm{W}_{i} 4: 58^{\circ} \mathrm{N} / 23^{\circ} \mathrm{W}_{;} 5: 72^{\circ} \mathrm{N} / 8^{\circ} \mathrm{W}$ 
(5) $72^{\circ} 00^{\prime} 00^{\prime \prime} \mathrm{N} / 08^{\circ} 24^{\prime} 58^{\prime \prime} \mathrm{W}$ to $72^{\circ} 09^{\prime} 07^{\prime \prime} N / 07^{\circ} 46^{\prime} 48^{\prime \prime} \mathrm{W}$ from $28^{\text {th }}$ June to $9^{\text {th }}$ July 1989 with 15 experiments.

The following measurements were performed:

(a) Water temperature $\left( \pm 0.002^{\circ} \mathrm{C}\right.$ ) and conductivity (transformed to salinity) $( \pm 0.004 \mathrm{~S}$ ): Neil-Brown Mark III CTD-profiler (continuous vertical profile measurements).

(b) Chlorophyll-a: Samples were taken with Niskin-bottles with a rosette-multisampler (fitted to the Neil-Brown CTD-profiler) at standard depths and measured according to the UNESCO-standard method. Using factors given by Eppley et al. (1973), these chlorophyll-measurements were converted to phytoplankton-carbon.

(c) Mesozooplankton community respiration: Zooplankton was caught in vertical net hauls from the pycnocline to the surface with a WP-2 net $(200 \mu \mathrm{m}$ mesh size). A subsample was incubated in the dark in $500 \mathrm{ml}$ sea water of the same location at actual water temperature for about 4 hours. Another subsample was treated with additional $100 \mathrm{mg}$ MABA (Sandoz) to anaesthetize the zooplankton and measure the phytoplankton- and microbe-oxygen uptake. Both bottles were locked with polarographic oxygen sensors, the oxygen content of the bottles being measured continuously. The difference between these two measurements gave the oxygen consumption of the mesozooplankton (Martens, 1986). If an oxygen saturation of less than $70 \%$ was reached, the experiment was terminated (Ikeda, 1977a). At the end of the experiment, one half of the incubated zooplankton was preserved with $2 \%$ formaldehyde solution for further microscopical analyses, the other half was dried for 24 hours in a desiccator and weighed on preweighed GF/C-filters on a semi-micro balance to determine the dry weight of the zooplankton incubated. For details of the method for respiration measurements, see Martens (1986).

The mean length of the zooplankter of each experiments was determined under the microscope in the laboratory after the expedition.

The oxygen consumption of the zooplankton was converted to carbon assimilated by factors given by Parsons et al. (1984) for the sake of better comparison between zooplankton respiration and phytoplankton standing stock.

A t-test on the significance of differences between the parameters measured at the five drifting stations was performed using Statgraphics Statistical Graphics System (STSC, 1987) on an ACER 900 under MS-DOS Version 3.3. The same software was used to compute a stepwise variable selection for the weight specific respiration rate and the determination of the Rank-correlation coefficients (after Spearman and after Kendall) between the parameters measured.

\section{RESULTS}

\section{The different drifting stations}

$18^{\circ} \mathrm{N}$ : The first experiment was situated in the transition zone between Canary Current and North Equatorial Current (Saure \& Podewski, 1990). The drifting buoy was launched on $26^{\text {th }}$ March 1989 and recovered on $6^{\text {th }}$ April 1989. The drifting area stretched from $18^{\circ} 19^{\prime} 26^{\prime \prime} \mathrm{N} / 29^{\circ} 35^{\prime} 53^{\prime \prime} \mathrm{W}$ to $18^{\circ} 48^{\prime} 25^{\prime \prime} \mathrm{N} / 30^{\circ} 40^{\prime} 55^{\prime \prime} \mathrm{W}$. Dependent on internal wave activity the depth of the main pycnocline was about 40 to $80 \mathrm{~m}$ (Saure \& Podewski, 1990). The mean temperature in the actual and winter mixed layer ranged from $21.53^{\circ} \mathrm{C}$ 
to $21.94{ }^{\circ} \mathrm{C}$ with a salinity of $36.57 \mathrm{~S}$ to $37.00 \mathrm{~S}$ (Fig. 3). The drifter passed a hydrographical front on April $1^{\text {st }}$ (Saure \& Podewski, 1990) and reached a water mass which was mainly characterized by the appearance of a subtropical salinity maximum. This is not reflected in the zooplankton population. The amount of zooplankton showed no marked changes (Fig. 2); only a slight decrease can be seen in the community respiration during these days. Relatively small zooplankter formed the mass of the population (mainly copepodites), the mean length being about $790 \mu \mathrm{m}$ (Table 1).

$33^{\circ} \mathrm{N}$ : The drift area was situated in the south-western branch of the Azores Current (Saure \& Podewski, 1990). The drifting buoy for the second experiment was launched on $15^{\text {th }}$ April 1989 and recovered on $24^{\text {th }}$ April 1989. The drifting area stretched from $33^{\circ} 56^{\prime} 53^{\prime \prime} \mathrm{N} / 20^{\circ} 55^{\prime} 44^{\prime \prime} \mathrm{W}$ to $33^{\circ} 13^{\prime} 01^{\prime \prime} \mathrm{N} / 21^{\circ} 24^{\prime} 44^{\prime \prime} \mathrm{W}$. Hydrographical investigations on a grid at the beginning of this experiment showed a weakly stratified watercolumn down to the main pycnocline at about 150-200 $\mathrm{m}$ depth. The drifter performed a cyclonic movement in the experimental area, no major hydrographical changes occurred during the experiment (Saure \& Podewski, 1990). The mean temperature ranged from $17.45^{\circ} \mathrm{C}$ to $18.04{ }^{\circ} \mathrm{C}$, the mean salinity from $36.33 \mathrm{~S}$ to $37.14 \mathrm{~S}$ (Figure 5), the small-scale variability being caused by advection and internal wave activity (Saure \& Podewski, 1990). As Figure 4 shows, major changes occur from April $20^{\text {th }}$ to $21^{\text {st }}$ in the zooplankton dry weight and especially in the community respiration which sinks to a minimum of $3.7 \mu \mathrm{g} \mathrm{O}_{2} \mathrm{~h}^{-1} \mathrm{~m}^{-3}$. On these days, the major part of the incubated zooplankton was formed by salps.

The mean length of the zooplankter was about $990 \mu \mathrm{m}$ (Table 1).

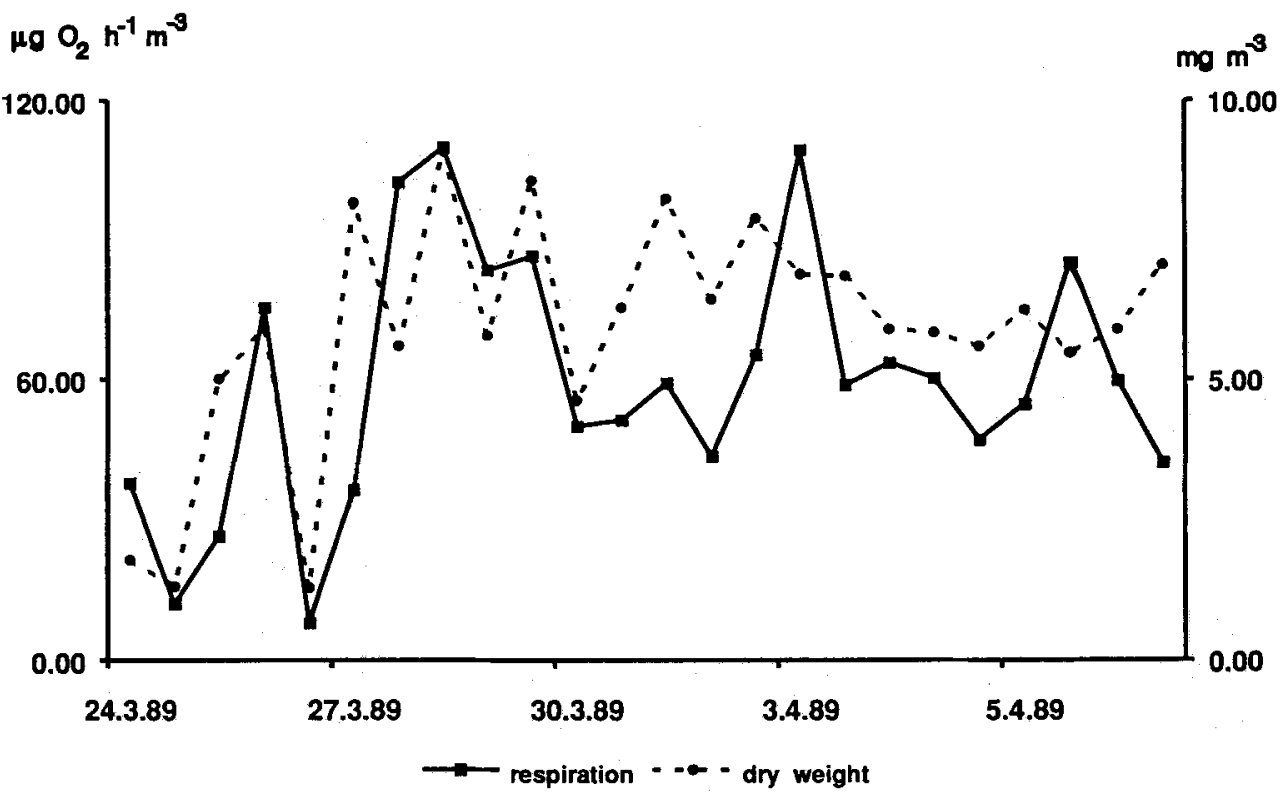

Fig. 2. Mesozooplankton respiration $\left(\mu \mathrm{g} \mathrm{O}_{2} \mathrm{~h}^{-1} \mathrm{~m}^{-3}\right)$ and zooplankton dry weight $\left(\mathrm{mg} \mathrm{m}^{-3}\right)$ during the first drifting station (mean value, upper $100 \mathrm{~m}$ water column) 


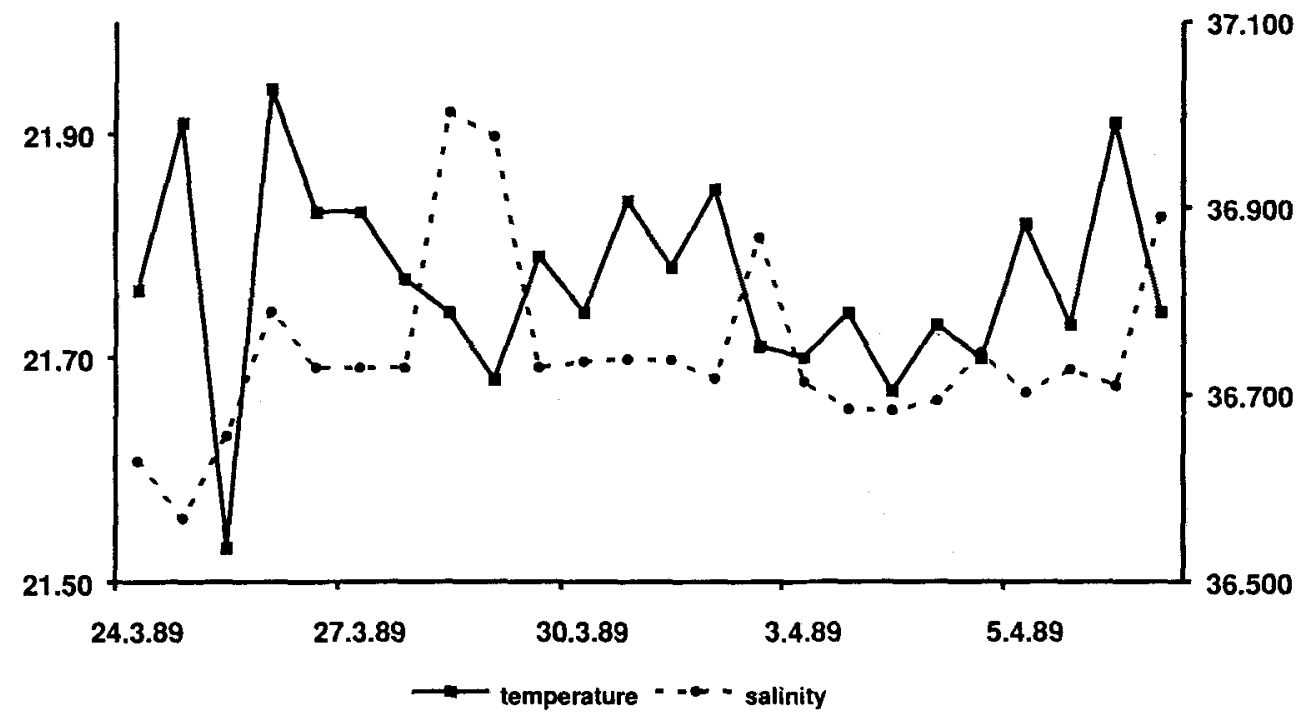

Fig. 3. Temperature and salinity during the first drifting station (mean value, upper $100 \mathrm{~m}$ water column)

$46^{\circ} \mathrm{N}$ : The drifting buoy for the third experiment was launched on $7^{\text {th }}$ May 1989 and recovered on $20^{\text {th }}$ May 1989 . The drifting area stretched from $46^{\circ} 30^{\prime} 43^{\prime \prime} N / 19^{\circ} 03^{\prime}$ $14^{\prime \prime} \mathrm{W}$ to $46^{\circ} 14^{\prime} 56^{\prime \prime} \mathrm{N} / 18^{\prime} 49^{\prime} 08^{\prime \prime} \mathrm{W}$. The rig drifted from the centre to the edge of a cyclonic smal eddy until May $15^{\text {th }}$ (Saure \& Podewski, 1990) with an anticyclonic

Table 1. Temperature $\left({ }^{\circ} \mathrm{C}\right)$, salinity $(\mathrm{S})$, mesozooplankton dry weight $\left(\mathrm{mg} \mathrm{m}^{-3}\right)$, community respiration $\left(\mu \mathrm{g} \mathrm{O}_{2} \mathrm{~h}^{-1} \mathrm{~m}^{-3}\right)$, weight-specific respiration rate $\left(\mu \mathrm{g} \mathrm{O}_{2} \mathrm{~h}^{-1} \mathrm{mg}^{-1} \mathrm{dw}\right)$, chlorophyll-a $\left(\mu \mathrm{g} \mathrm{I}^{-1}\right)$ and length of the zooplankter $(\mu \mathrm{m})$ (all mean values above the pycnocline) at the five drifting stations $\left(18^{\circ} \mathrm{N}\right.$ to $\left.72^{\circ} \mathrm{N}\right)$

\begin{tabular}{|lcrrrrrr|}
\hline Latitude & $\begin{array}{c}\text { Tempera- } \\
\text { ture }\left({ }^{\circ} \mathrm{C}\right)\end{array}$ & $\begin{array}{c}\text { Salinity } \\
(\mathbf{S})\end{array}$ & $\begin{array}{c}\text { Zoopl. } \\
\text { dry weight }\end{array}$ & $\begin{array}{c}\text { Comm. } \\
\text { respiration }\end{array}$ & $\begin{array}{c}\text { Weight } \\
\text { spec.resp. }\end{array}$ & chl-a & $\begin{array}{c}\text { Animal } \\
\text { length }\end{array}$ \\
\hline $18^{\circ} \mathrm{N}$ & 21.77 & 36.745 & 5.90 & 59.52 & 10.40 & 0.31 & 787 \\
& \pm 0.09 & \pm 0.100 & \pm 2.06 & \pm 27.20 & \pm 4.19 & \pm 0.003 & \pm 292 \\
$33^{\circ} \mathrm{N}$ & 17.78 & 36.544 & 11.39 & 88.45 & 8.38 & 0.49 & 993 \\
& \pm 0.18 & \pm 0.151 & \pm 4.36 & \pm 40.11 & \pm 4.14 & \pm 0.02 & \pm 117 \\
$47^{\circ} \mathrm{N}$ & 13.27 & 35.630 & 16.91 & 61.94 & 3.73 & 1.10 & 909 \\
& \pm 0.38 & \pm 0.010 & \pm 10.39 & \pm 57.09 & \pm 3.18 & \pm 0.41 & \pm 71 \\
$58^{\circ} \mathrm{N}$ & 9.76 & 35.246 & 24.56 & 71.79 & 3.06 & 0.94 & 1023 \\
& \pm 0.32 & \pm 0.011 & \pm 21.67 & \pm 65.91 & \pm 0.97 & \pm 0.23 & \pm 136 \\
$72^{\circ} \mathrm{N}$ & 2.08 & 34.275 & 59.17 & 62.34 & 1.14 & 0.64 & 1178 \\
& \pm 1.25 & \pm 0.262 & \pm 29.96 & \pm 40.16 & \pm 0.58 & \pm 0.36 & \pm 248 \\
& & & & & & & \\
\hline
\end{tabular}




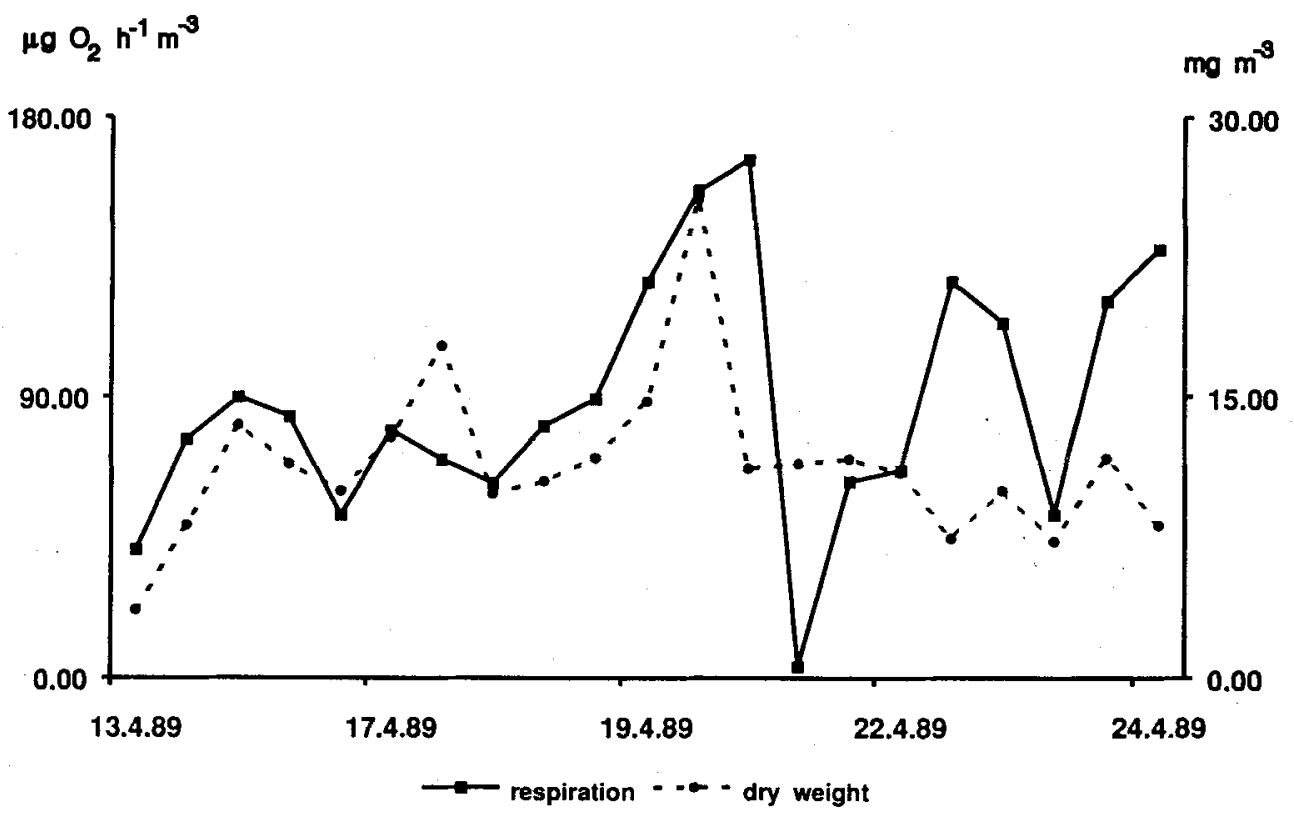

Fig. 4. Mesozooplankton respiration $\left(\mu \mathrm{g} \mathrm{O}_{2} \mathrm{~h}^{-1} \mathrm{~m}^{-3}\right)$ and zooplankton dry weight $\left(\mathrm{mg} \mathrm{m}^{-3}\right)$ during the second drifting station (mean value, upper $200 \mathrm{~m}$ water column)

$t(C)$

$\mathbf{S}$

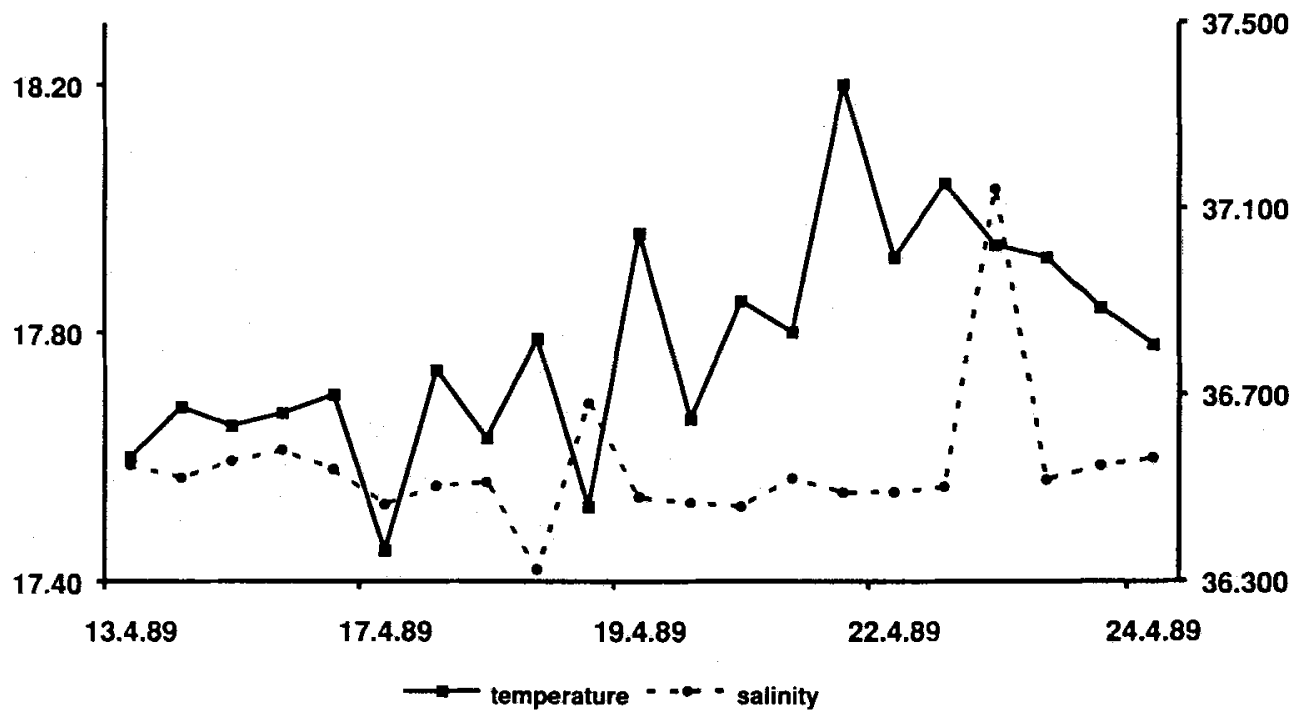

Fig. 5. Temperature and salinity during the second drifting station (mean value, upper $100 \mathrm{~m}$ water column) 
structure showing up at the western border of the investigation area (Robinson et al., 1992). The mixed layer stretched down to $80 \mathrm{~m}$ at the maximum. The mean temperature ranged from $12.38^{\circ} \mathrm{C}$ to $14.17^{\circ} \mathrm{C}$, the mean salinity.ranged from $35.61 \mathrm{~S}$ to $35.65 \mathrm{~S}$. Figure 6 shows an increase in the amount of zooplankton as well as in the community respiration after May $15^{\text {th }}$ when the small eddy was left reflecting different zooplankton communities in different water masses. Figure 7 shows the marked increase in salinity observed during these days.

The mean length of the zooplankter was about $910 \mu \mathrm{m}$ (Table 1).

$58^{\circ} \mathrm{N}$ : The drifting buoy for the fourth experiment was launched on $28^{\text {th }}$ May 1989 and recovered on $8^{\text {th }}$ June 1989 . The drifting area stretched from $57^{\circ} 39^{\prime} 07^{\prime \prime} N / 23^{\circ} 13^{\prime}$ $12^{\prime \prime} \mathrm{W}$ to $58^{\circ} 18^{\prime} 00^{\prime \prime} \mathrm{N} / 24^{\circ} 40^{\prime} 19^{\prime \prime} \mathrm{W}$. The drifter trajectory formed half an anticyclonic cycle (Saure \& Podewski, 1990); the depth of the mixed layer decreased slightly to $100 \mathrm{~m}$ during the time of experiment. The mean temperature ranged from $9.13^{\circ} \mathrm{C}$ to $10.37^{\circ} \mathrm{C}$, the mean salinity ranged from $35.23 \mathrm{~S}$ to $35.26 \mathrm{~S}$. Figures 8 and 9 show that community respiration and zooplankton dry weight increased on the last day of the experiment whereas temperature and salinity decreased. A CTD-section performed during this time shows that a frontal region existed to the north-east of the drifting region (Saure \& Podewski, 1990).

The mean length of the zooplankter was about $1020 \mu \mathrm{m}$ (Table 1).

$72^{\circ} \mathrm{N}$ : The drifting buoy for the fifth experiment was launched on $28^{\text {th }}$ June 1989 and recovered on $9^{\text {th }}$ July 1989 . The drifting area stretched from $72^{\circ} 00^{\prime} 00^{\prime \prime} N / 08^{\circ} 24^{\prime}$ $58^{\prime \prime} \mathrm{W}$ to $72^{\circ} 09^{\prime} 07^{\prime \prime} \mathrm{N} / 07^{\circ} 46^{\prime} 48^{\prime \prime} \mathrm{W}$ and was situated in the Greenland Basin north of Jan Mayen. Hydrographically, it was strongly influenced by the Marginal Ice Zone (Saure \& Podewski, 1990). Temperature and salinity varied strongly compared to the other drifting areas (Figure 11), the mean temperature ranging from $1.26^{\circ} \mathrm{C}$ to $2.31{ }^{\circ} \mathrm{C}$, the mean salinity from $33.73 \mathrm{~S}$ to $34.34 \mathrm{~S}$. Marked decrease and increase of temperature and salinity at the beginning of the experiment were caused by a frontal region in the surface layer showing meandering hydrographical structures (Saure \& Podewski, 1990). So different hydrograhic regimes were found during this experiment. The main pycnocline was about $30 \mathrm{~m}$. Samples were taken down to $180 \mathrm{~m}$ (polar water transported with the Jan Mayen Current). The community respiration and the zooplankton dry weight reflected the strong variability in this region (Figure 10).

The mean length of zooplankter was about $1180 \mu \mathrm{m}$ (Table 1) with large calanoid copepods (Calanus hyperboreus).

\section{Comparison of the drifting stations}

As could be expected there was a decrease in temperature from south to north as can be seen from Figure 12. The differences between the mean temperatures were significant on the $0.1 \%$-level (Table 2). The same holds true for salinity (Table 3 ).

Parallel to temperature, the weight-specific respiration rate decreased (Figure 12) with significant differences between most of the drifting areas (Table 6).

As can be seen from Figure 13, the mean amount of mesozooplankton in the mixed layer increased from south to north with significant differences between most of the drifting areas (Table 5).

The combination of the amount of zooplankton and the weight-specific respiration 


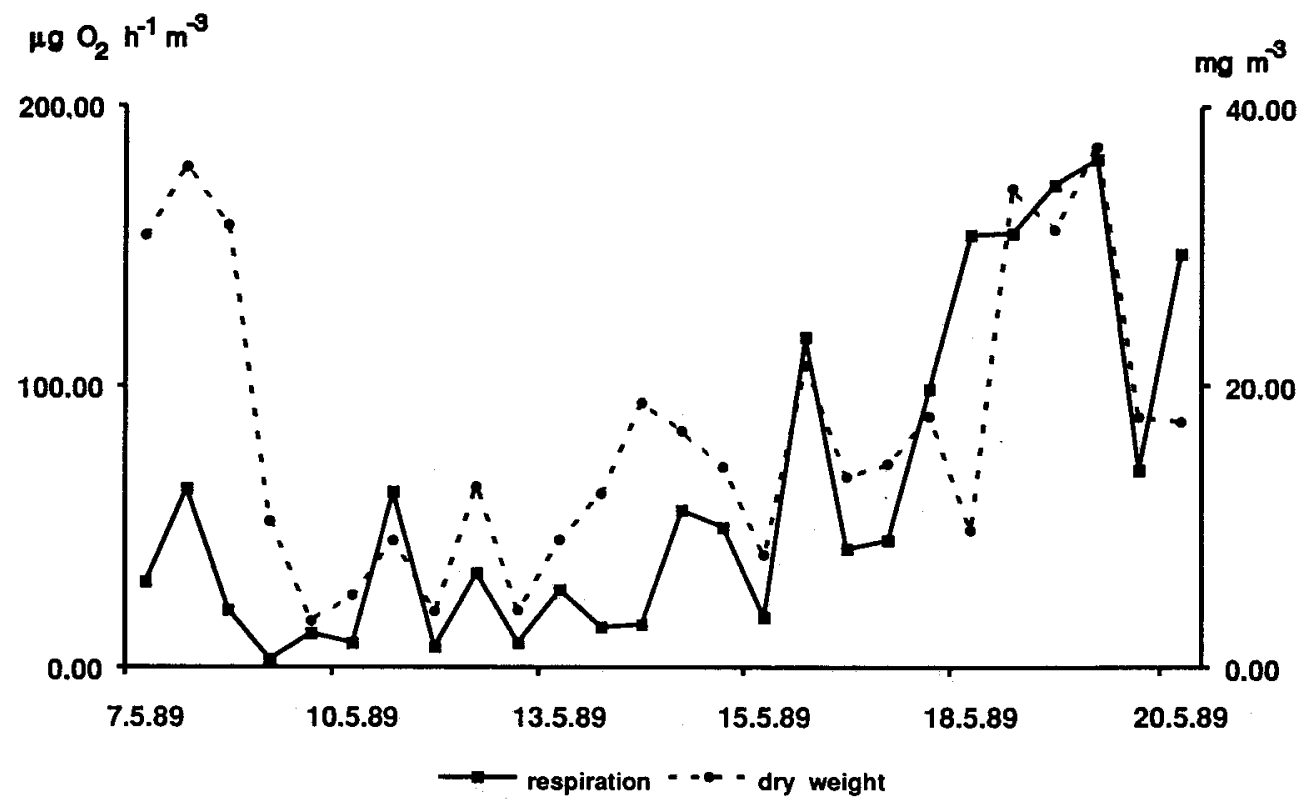

Fig. 6. Mesozooplankton respiration $\left(\mu \mathrm{g} \mathrm{O} \mathrm{O}_{2} \mathrm{~h}^{-1} \mathrm{~m}^{-3}\right)$ and zooplankton dry weight $\left(\mathrm{mg} \mathrm{m}^{-3}\right)$ during the third drifting station (mean value, upper $80 \mathrm{~m}$ water column)

t (C)

$\mathbf{S}$

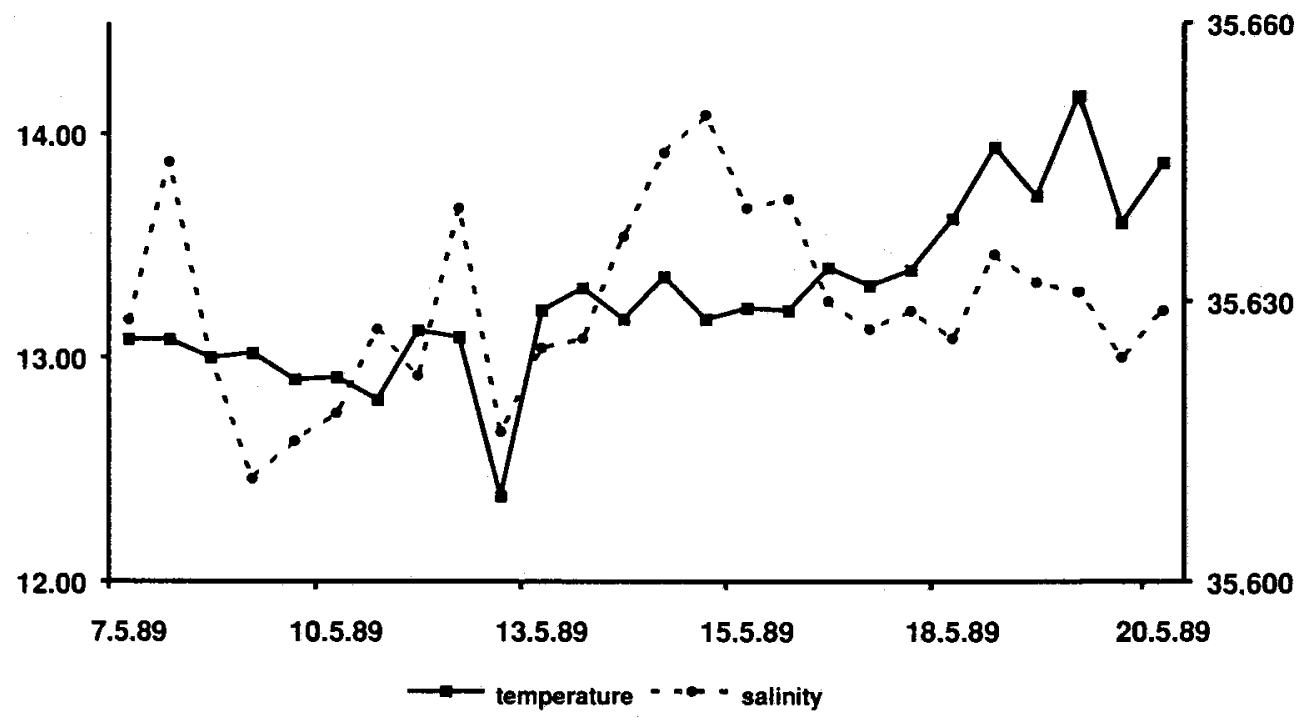

Fig. 7. Temperature and salinity during the third drifting station (mean value, upper $80 \mathrm{~m}$ water column) 


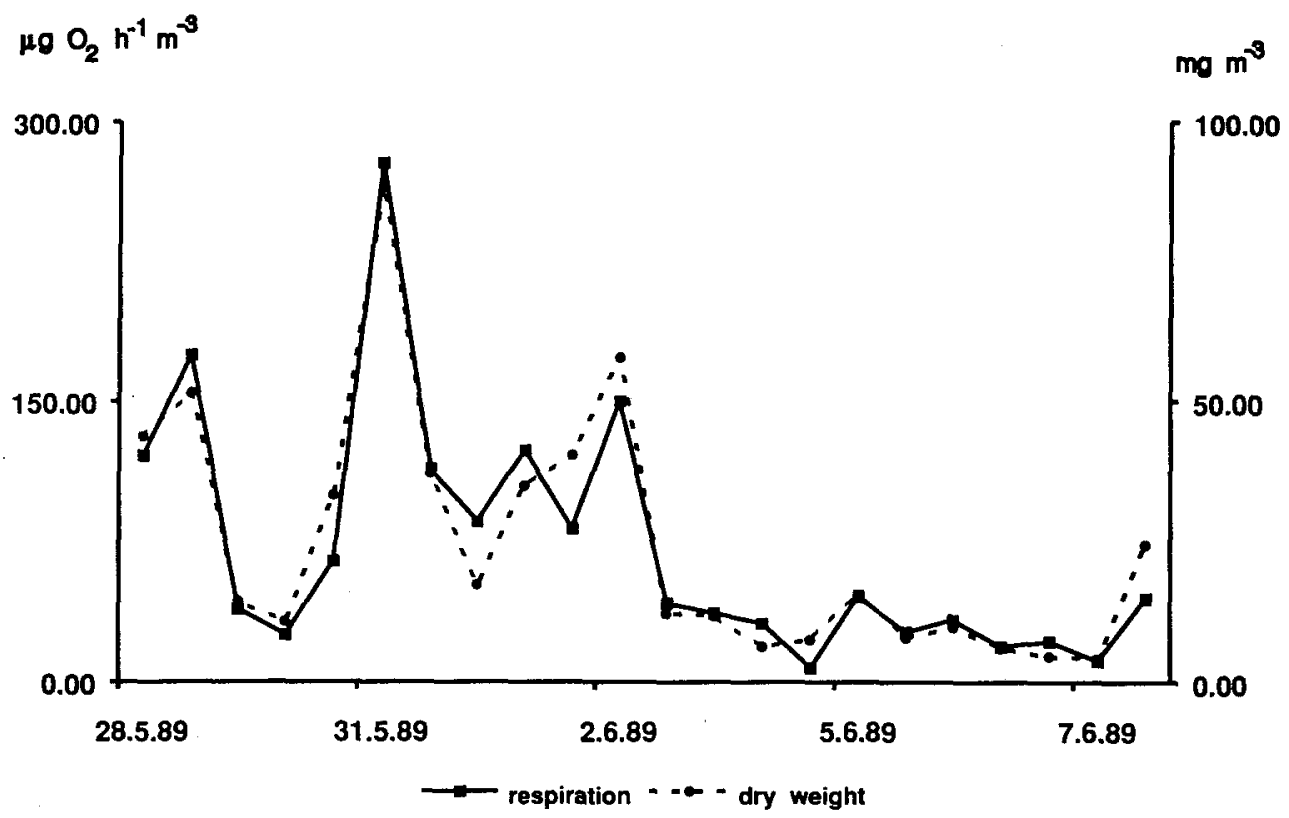

Fig. 8. Mesozooplankton respiration $\left(\mu \mathrm{g} \mathrm{O}_{2} \mathrm{~h}^{-1} \mathrm{~m}^{-3}\right)$ and zooplankton dry weight $\left(\mathrm{mg} \mathrm{m}^{-3}\right)$ during the fourth drifting station (mean value, upper $100 \mathrm{~m}$ water column)

$t(C)$

s

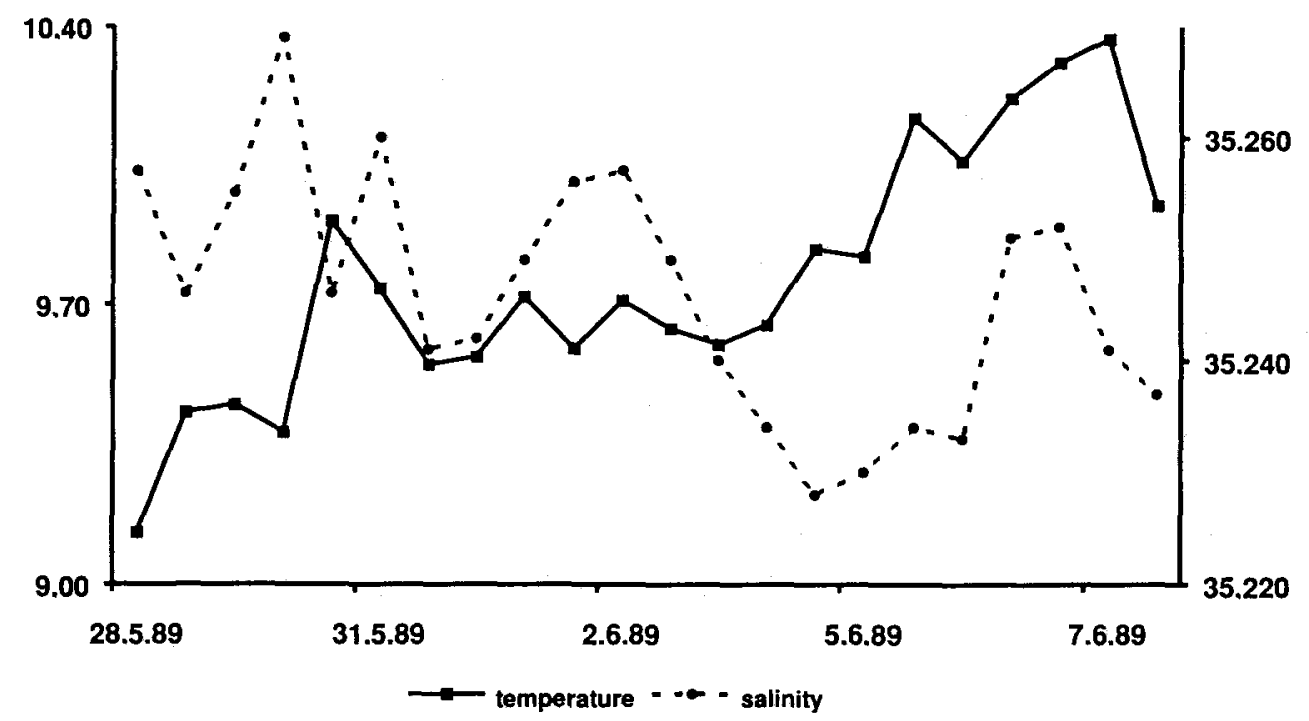

Fig. 9. Temperature and salinity during the fourth drifting station (mean value, upper $100 \mathrm{~m}$ water column) 


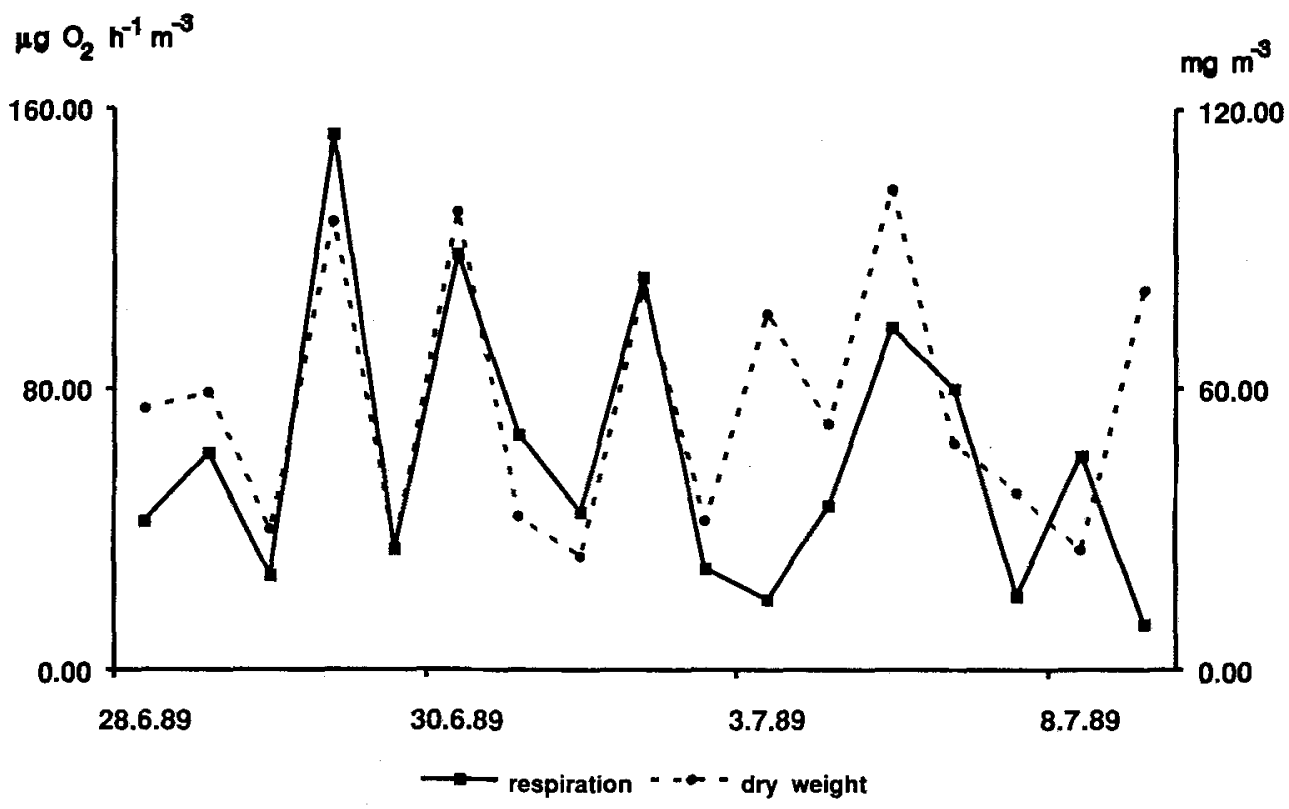

Fig. 10. Mesozooplankton respiration $\left(\mu \mathrm{g} \mathrm{O}_{2} \mathrm{~h}^{-1} \mathrm{~m}^{-3}\right)$ and zooplankton dry weight $\left(\mathrm{mg} \mathrm{m}^{-3}\right)$ during the fifth drifting station (mean value, upper $180 \mathrm{~m}$ water column)

t(C)

s

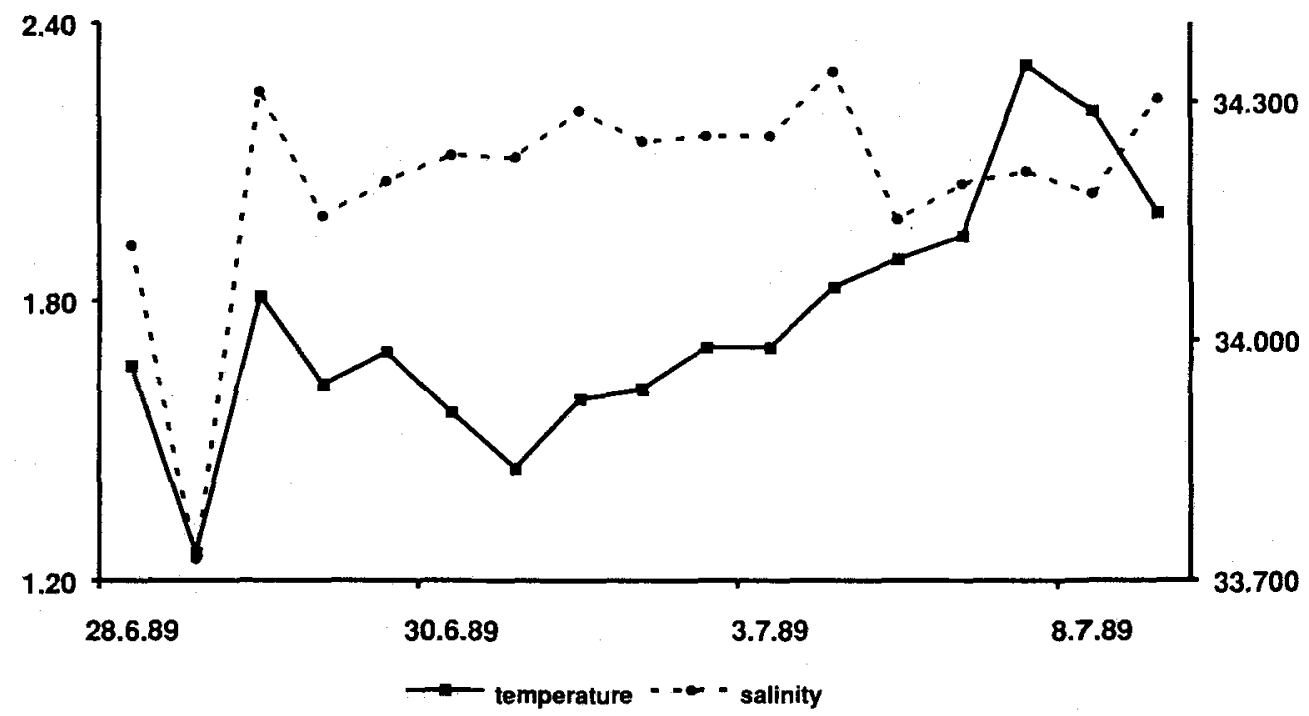

Fig. 11. Temperature and salinity during the fifth drifting station (mean value, upper $180 \mathrm{~m}$ water column) 
Table 2. Test on the significance of the differences of the mean water temperature (above the pycnocline) at the five drifting stations. Computed $t$-values with level of significance (rejection of 0 hypothesis at $\mathrm{P} \leq 5 \%$ )

\begin{tabular}{|clllll|}
\hline Latitude & $18^{\circ} \mathrm{N}$ & \multicolumn{1}{c}{$33^{\circ} \mathrm{N}$} & $47^{\circ} \mathrm{N}$ & \multicolumn{1}{c}{$58^{\circ} \mathrm{N}$} & \multicolumn{1}{c}{$72^{\circ} \mathrm{N}$} \\
\hline $18^{\circ} \mathrm{N}$ & & +96.21 & $\begin{array}{l}+106.06 \\
(<0.1 \%)\end{array}$ & $\begin{array}{l}+177.50 \\
(<0.1 \%)\end{array}$ & $\begin{array}{l}+77.38 \\
(<0.1 \%)\end{array}$ \\
$33^{\circ} \mathrm{N}$ & -96.21 & $(<0.1 \%)$ & $\begin{array}{l}+49.68 \\
+101.10\end{array}$ & +57.15 \\
& & & $(<0.1 \%)$ & $(<0.1 \%)$ & $(<0.1 \%)$ \\
$47^{\circ} \mathrm{N}$ & -106.06 & -49.68 & & +3.15 & +43.25 \\
& $(<0.1 \%)$ & $(<0.1 \%)$ & & $(<0.1 \%)$ & $(<0.1 \%)$ \\
$58^{\circ} \mathrm{N}$ & -177.50 & -101.10 & -3.15 & & +27.94 \\
& $(<0.1 \%)$ & $(<0.1 \%)$ & $(<0.1 \%)$ & & $(<0.1 \%)$ \\
$72^{\circ} \mathrm{N}$ & -77.38 & -57.15 & -43.25 & -27.94 & \\
& $(<0.1 \%)$ & $(<0.1 \%)$ & $(<0.1 \%)$ & $(<0.1 \%)$ & \\
\hline
\end{tabular}

Table 3 . Test on the significance of the differences of the mean salinity (above the pycnocline) at the five drifting stations. Computed t-values with level of significance (rejection of 0 -hypothesis at $P \leq 5 \%)$

\begin{tabular}{|c|c|c|c|c|c|}
\hline Latitude & $18^{\circ} \mathrm{N}$ & $33^{\circ} \mathrm{N}$ & $47^{\circ} \mathrm{N}$ & $58^{\circ} \mathrm{N}$ & $72^{\circ} \mathrm{N}$ \\
\hline $18^{\circ} \mathrm{N}$ & & $\begin{array}{l}+5.34 \\
(<0.1 \%)\end{array}$ & $\begin{array}{l}+56.94 \\
(<0.1 \%)\end{array}$ & $\begin{array}{l}+70.28 \\
(<0.1 \%)\end{array}$ & $\begin{array}{l}+42.53 \\
(<0.1 \%)\end{array}$ \\
\hline $33^{\circ} \mathrm{N}$ & $\begin{array}{l}-5.34 \\
(<0.1 \%)\end{array}$ & & $\begin{array}{l}+30.77 \\
(<0.1 \%)\end{array}$ & $\begin{array}{l}+40.12 \\
(<0.1 \%)\end{array}$ & $\begin{array}{l}+33.90 \\
(<0.1 \%)\end{array}$ \\
\hline $47^{\circ} \mathrm{N}$ & $\begin{array}{l}-56.94 \\
(<0.1 \%)\end{array}$ & $\begin{array}{l}-30.77 \\
(<0.1 \%)\end{array}$ & & $\begin{array}{l}+128.85 \\
(<0.1 \%)\end{array}$ & $\begin{array}{l}+26.42 \\
(<0.1 \%)\end{array}$ \\
\hline $58^{\circ} \mathrm{N}$ & $\begin{array}{l}-70.28 \\
(<0.1 \%)\end{array}$ & $\begin{array}{l}-40.12 \\
(<0.1 \%)\end{array}$ & $\begin{array}{l}-128.85 \\
(<0.1 \%)\end{array}$ & & $\begin{array}{l}+17.37 \\
(<0.1 \%)\end{array}$ \\
\hline $72^{\circ} \mathrm{N}$ & $\begin{array}{l}-42.53 \\
(<0.1 \%)\end{array}$ & $\begin{array}{l}-33.90 \\
(<0.1 \%)\end{array}$ & $\begin{array}{l}-26.42 \\
(<0.1 \%)\end{array}$ & $\begin{array}{l}-17.37 \\
(<0.1 \%)\end{array}$ & \\
\hline
\end{tabular}

rate gives the oxygen consumption of the mesozooplankton community (the so called community respiration). No great differences could be found between the five drifting areas (Figure 13). Only in two out of ten cases could a statistically significant difference be observed (Table 4).

To compare the respiration rate of the mesozooplankton with that of the phytoplankton standing stock, both were converted to units of carbon (Parsons et al., 1984; Eppley et al., 1973). Figure 14 shows the mean amount of carbon assimilated by the mesozooplankton per day in comparison to the phytoplankton carbon on a logarithmic scale. It ranges from $0.8 \%$ to $2 \%$. Several parameters were measured during these experiments temperature, salinity, length of the zooplankter, available food in form of chlorophyll-a. To see how these parameters influence the weight-specific respiration rate, a stepwise 


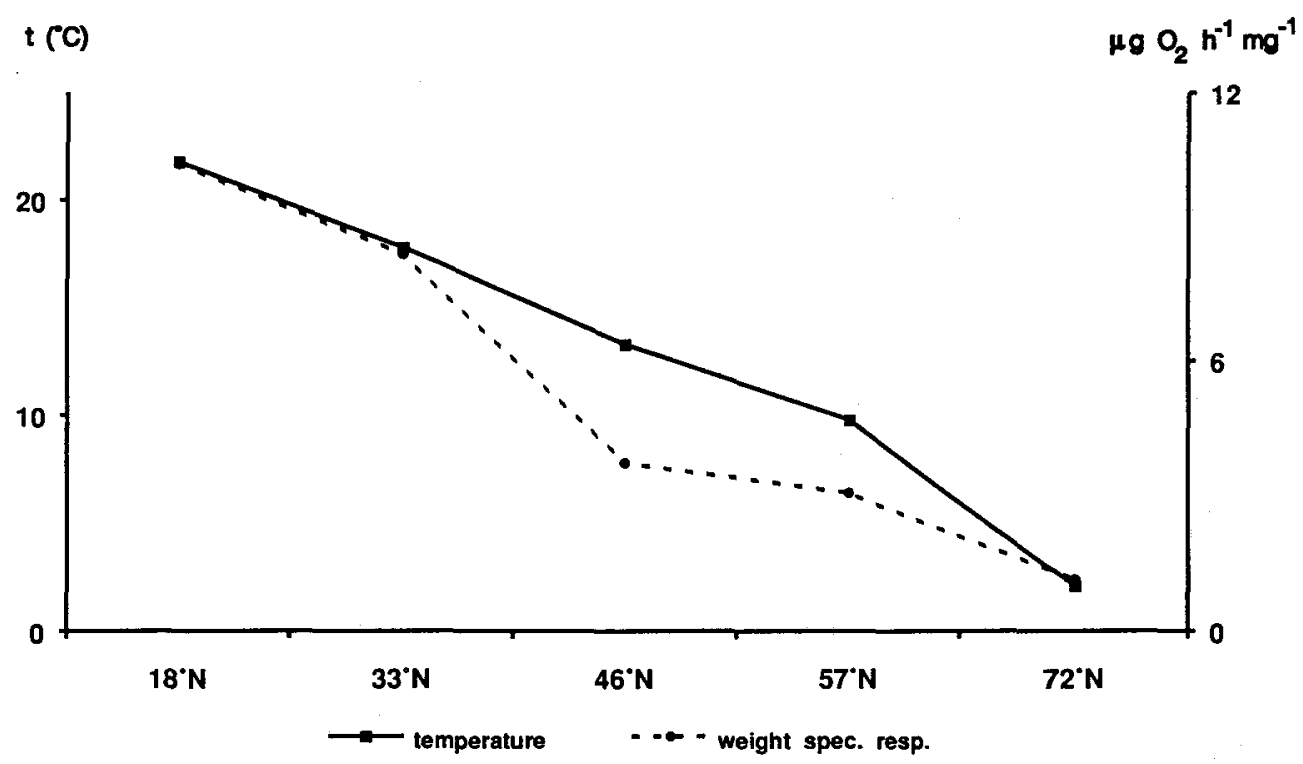

Fig. 12. Comparison of the mean water temperature $\left({ }^{\circ} \mathrm{C}\right)$ above the pycnocline at the five drifting stations (northern latitude) and of the weight-specific respiration rate $\left(\mu \mathrm{O} \mathrm{O}_{2} \mathrm{~h}^{-1} \mathrm{mg}^{-1}\right.$ dry weight)

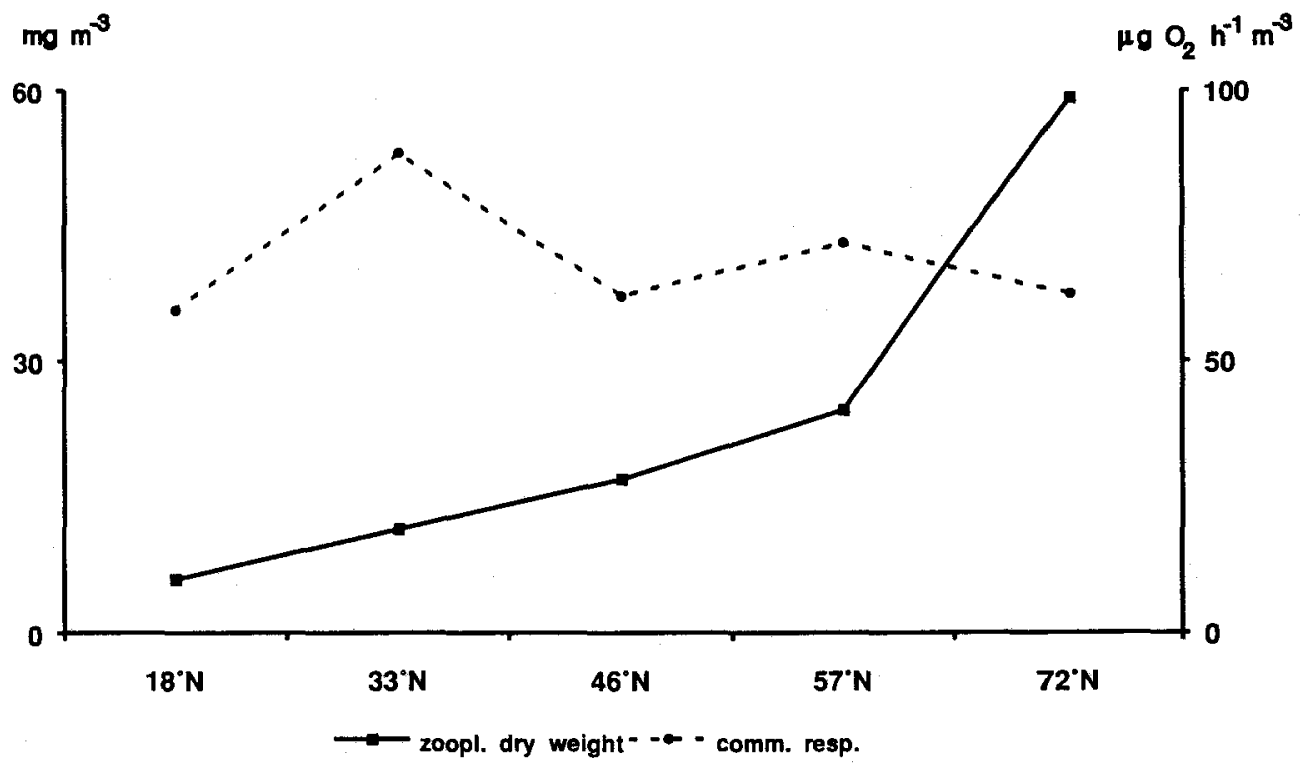

Fig. 13. Comparison of the mean mesozooplankton dry weight $\left(\mathrm{mg} \mathrm{dw} \mathrm{m}^{-3}\right)$ above the pycnocline at the five drifting stations (northern latitude) and of the community respiration rate $\left(\mu \mathrm{O} \mathrm{O}_{2} \mathrm{~h}^{-1} \mathrm{~m}^{-3}\right.$ ) 
Table 4. Test on the significance of the differences of the mean community respiration (oxygen consumed by the mesozooplankton community) (above the pycnocline) at the five drifting stations. Computed $t$-values with level of significance (rejection of 0 -hypothesis at $\mathrm{P} \leq 5 \%$ )

\begin{tabular}{|cccccc|}
\hline Latitude & $18^{\circ} \mathrm{N}$ & $33^{\circ} \mathrm{N}$ & $47^{\circ} \mathrm{N}$ & $58^{\circ} \mathrm{N}$ & $72^{\circ} \mathrm{N}$ \\
\hline \multirow{2}{*}{$18^{\circ} \mathrm{N}$} & & -2.863 & -0.189 & -0.838 & -0.274 \\
& & $(0.6 \%)$ & $(85 \%)$ & $(41 \%)$ & $(79 \%)$ \\
$33^{\circ} \mathrm{N}$ & +2.863 & & -1.798 & +0.996 & -2.055 \\
& $(0.6 \%)$ & & $(8 \%)$ & $(33 \%)$ & $(4.7 \%)$ \\
$47^{\circ} \mathrm{N}$ & +0.189 & +1.798 & & +0.555 & -0.026 \\
& $(85 \%)$ & $(8 \%)$ & & $(58 \%)$ & $(98 \%)$ \\
$58^{\circ} \mathrm{N}$ & +0.838 & -0.996 & -0.555 & & +0.543 \\
& $(41 \%)$ & $(33 \%)$ & $(58 \%)$ & & $(59 \%)$ \\
$72^{\circ} \mathrm{N}$ & +0.274 & +2.055 & +0.026 & -0.543 & \\
& $(79 \%)$ & $(4.7 \%)$ & $(98 \%)$ & $(59 \%)$ & \\
\hline
\end{tabular}

Table 5. Test on the significance of the differences of the mean mesozooplankton dry weight (above the pycnocline) at the five drifting stations. Computed t-values with level of significance (rejection of 0 -hypothesis at $\mathrm{P} \leq 5 \%$ )

\begin{tabular}{|clllll|}
\hline Latitude & $18^{\circ} \mathrm{N}$ & $33^{\circ} \mathrm{N}$ & \multicolumn{1}{c}{$47^{\circ} \mathrm{N}$} & \multicolumn{1}{c}{$58^{\circ} \mathrm{N}$} & \multicolumn{1}{c}{$72^{\circ} \mathrm{N}$} \\
\hline $18^{\circ} \mathrm{N}$ & & -5.510 & -5.095 & -4.201 & -8.713 \\
& & $(<0.1 \%)$ & $(<0.1 \%)$ & $(<0.1 \%)$ & $(<0.1 \%)$ \\
$33^{\circ} \mathrm{N}$ & +5.510 & & -2.274 & -2.730 & -7.234 \\
& $(<0.1 \%)$ & & $(2.8 \%)$ & $(0.9 \%)$ & $(<0.1 \%)$ \\
$47^{\circ} \mathrm{N}$ & +5.095 & +2.274 & & -1.598 & -6.687 \\
& $(<0.1 \%)$ & $(2.8 \%)$ & & $(12 \%)$ & $(<0.1 \%)$ \\
$58^{\circ} \mathrm{N}$ & +4.201 & +2.730 & +1.598 & & -4.279 \\
& $(<0.1 \%)$ & $(0.9 \%)$ & $(12 \%)$ & & $(<0.1 \%)$ \\
$72^{\circ} \mathrm{N}$ & +8.713 & +7.234 & +6.687 & +4.279 & \\
& $(<0.1 \%)$ & $(<0.1 \%)$ & $(<0.1 \%)$ & $(<0.1 \%)$ & \\
\hline
\end{tabular}

variable selection was performed. To achieve a better fit with the normal distribution, all values were log-transformed. Table 9 gives the results of this computation. Water temperature and the mean animal length exert a significant influence on the weight-specific respiration rate, whereas neither salinity nor chlorophyll-a play an important role. A decrease in water temperature leads to a decrease in the weight-specific respiration rate whereas an increase in the mean animal length has the same effect.

Two non-parametric methods have been used (Rank-correlation after Spearman and after Kendall) to verify the results of the parametric methods (Table 9). 
Table 6. Test on the significance of the differences of the mean mesozooplankton respiration per dry weight (weight-specific respiration) (above the pycnocline) at the five drifting stations. Computed t-values with level of significance (rejection of 0 -hypothesis at $\mathrm{P} \leq 5 \%$ )

\begin{tabular}{|clllll|}
\hline Latitude & $18^{\circ} \mathrm{N}$ & $33^{\circ} \mathrm{N}$ & $47^{\circ} \mathrm{N}$ & $58^{\circ} \mathrm{N}$ & \multicolumn{1}{c}{$72^{\circ} \mathrm{N}$} \\
\hline $18^{\circ} \mathrm{N}$ & & $\begin{array}{l}+1.626 \\
(11 \%)\end{array}$ & $\begin{array}{l}+6.371 \\
(<0.1 \%)\end{array}$ & $\begin{array}{l}+8.018 \\
(<0.1 \%)\end{array}$ & $\begin{array}{l}+9.537 \\
(<0.1 \%)\end{array}$ \\
$33^{\circ} \mathrm{N}$ & -1.626 & & +4.354 & +5.867 & +7.547 \\
& $(11 \%)$ & & $(<0.1 \%)$ & $(<0.1 \%)$ & $(<0.1 \%)$ \\
$47^{\circ} \mathrm{N}$ & -6.371 & -4.354 & & +0.959 & +3.501 \\
& $(<0.1 \%)$ & $(<0.1 \%)$ & & $(34 \%)$ & $(<0.1 \%)$ \\
$58^{\circ} \mathrm{N}$ & -8.018 & -5.867 & -0.959 & & +7.518 \\
& $(<0.1 \%)$ & $(<0.1 \%)$ & $(34 \%)$ & & $(<0.1 \%)$ \\
$72^{\circ} \mathrm{N}$ & -9.537 & -7.547 & -3.501 & -7.518 & $(<0.1 \%)$ \\
& $(<0.1 \%)$ & $(<0.1 \%)$ & $(<0.1 \%)$ & $(<.1 \%)$ \\
\hline
\end{tabular}

$\mathrm{mgC} \mathrm{m} / \mathrm{mgC} \mathrm{m} \mathrm{m}^{-1}$

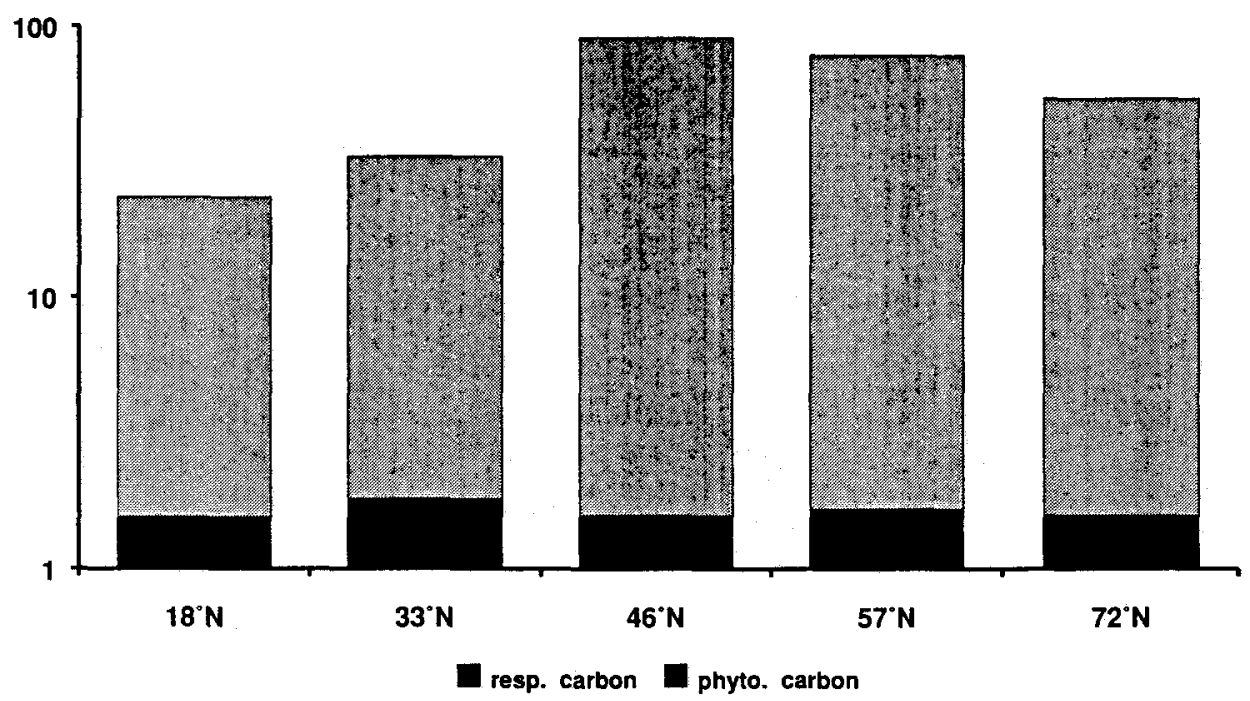

Fig. 14. Comparison of the carbon used by mesozooplankton during respiration above the pycnocline ( $\mathrm{mg} \mathrm{C} \mathrm{d}^{-1} \mathrm{~m}^{-3}$ ) at the five drifting stations (northern latitude) and of the phytoplankton carbon ( $\mathrm{mg} \mathrm{C} \mathrm{m} \mathrm{m}^{-3}$ ). Converted from respiration measurements after Parsons et al. (1984) and from chl-a measurements after Eppley et al. (1973). (Y-axis: $n+1$; $\log$-scale)

\section{DISCUSSION}

JGOFS has two main goals as defined in the science plan:

G o a l 1: To determine and understand on a global scale the processes controlling the time-varying fluxes of carbon and associated biogenic elements in the ocean, and to 
Table 7. Test on the significance of the differences of the mean chlorophyll-a content (above the pycnocline) at the five drifting stations. Computed t-values with level of significance (rejection of 0 hypothesis at $\mathrm{P} \leq 5 \%$ )

\begin{tabular}{|clllll|}
\hline Latitude & $18^{\circ} \mathrm{N}$ & $33^{\circ} \mathrm{N}$ & $47^{\circ} \mathrm{N}$ & $58^{\circ} \mathrm{N}$ & $72^{\circ} \mathrm{N}$ \\
\hline $18^{\circ} \mathrm{N}$ & & -5.504 & -8.706 & -12.305 & -4.107 \\
& & $(<0.1 \%)$ & $(<0.1 \%)$ & $(<0.1 \%)$ & $(<0.1 \%)$ \\
$33^{\circ} \mathrm{N}$ & +5.504 & & -6.553 & -7.9166 & -1.803 \\
& $(<0.1 \%)$ & & $(<0.1 \%)$ & $(<0.1 \%)$ & $(8.0 \%)$ \\
$47^{\circ} \mathrm{N}$ & +8.706 & +6.553 & & +1.644 & +3.754 \\
& $(<0.1 \%)$ & $(<0.1 \%)$ & & $(10.7 \%)$ & $(<0.1 \%)$ \\
$58^{\circ} \mathrm{N}$ & +12.305 & +7.9166 & -1.644 & & +3.148 \\
& $(<0.1 \%)$ & $(<0.1 \%)$ & $(10.7 \%)$ & & $(<0.1 \%)$ \\
$72^{\circ} \mathrm{N}$ & +4.107 & +1.803 & -3.754 & -3.148 & \\
& $(<0.1 \%)$ & $(8.0 \%)$ & $(<0.1 \%)$ & $(<0.1 \%)$ & \\
\hline
\end{tabular}

Table 8. Test on the significance of the differences of the mean length of the mesozooplankter (above the pycnocline) at the five drifting stations. Computed t-values with level of significance (rejection of 0 -hypothesis at $\mathrm{P} \leq 5 \%$ )

\begin{tabular}{|cccccc|}
\hline Latitude & $18^{\circ} \mathrm{N}$ & $33^{\circ} \mathrm{N}$ & $47^{\circ} \mathrm{N}$ & $58^{\circ} \mathrm{N}$ & $72^{\circ} \mathrm{N}$ \\
\hline \multirow{2}{*}{$18^{\circ} \mathrm{N}$} & & -.038 & -2.071 & -3.471 & -4.659 \\
& & $(<1 \%)$ & $(<5 \%)$ & $(<1 \%)$ & $(<0.1 \%)$ \\
$33^{\circ} \mathrm{N}$ & +3.038 & & +3.062 & -0.774 & -3.058 \\
& $(<1 \%)$ & & $(<1 \%)$ & $(50 \%)$ & $(<1 \%)$ \\
$47^{\circ} \mathrm{N}$ & +2.071 & -3.062 & & -3.743 & -5.259 \\
& $(<5 \%)$ & $(<1 \%)$ & & $(<1 \%)$ & $(<0.1 \%)$ \\
$58^{\circ} \mathrm{N}$ & +3.471 & +0.774 & +3.743 & & -2.520 \\
& $(<1 \%)$ & $(50 \%)$ & $(<1 \%)$ & & $(<5 \%)$ \\
$72^{\circ} \mathrm{N}$ & +4.659 & +3.058 & +5.259 & +2.520 & $(<5 \%)$ \\
& $(<0.1 \%)$ & $(<1 \%)$ & $(<0.1 \%)$ & & \\
\hline
\end{tabular}

evaluate the related exchanges with the atmosphere, sea floor, and continental boundaries.

Goa 12 : To develop a capability to predict on a global scale the response of oceanic biogeochemical processes to anthropogenic perturbations, in particular those related to climate changes (JGOFS, 1990).

The zooplankton plays an important role in the transformation of matter within the marine food web; together with microbes it remineralizes one part of the organic matter formed by the phytoplankton and on the other hand serves as food for the higher trophic levels. Difficulties arise when it comes to the more practical question of how to quantify this influence.

To evaluate primary production, standard methods have been widely accepted, for 
Table 9. Influence of water temperature and mean length of the zooplankter on the weight-specific respiration rate

\begin{tabular}{lcc}
$\begin{array}{l}\text { Para metric meth ods s } \\
\text { Independent variable }\end{array}$ & $\begin{array}{c}\text { (stepwise variable selection) } \\
\text { t-value }\end{array}$ & $\begin{array}{c}\text { (all values log-transformed) } \\
\text { Level of significance }\end{array}$ \\
\hline $\begin{array}{l}\text { Water temperature } \\
\text { Mean length }\end{array}$ & 10.45 & $0.01 \%$ \\
R-Squared: 0.800 & -3.41 & $0.09 \%$ \\
log (weight spec. resp.) $=0.825^{*} \log$ (temperature) $-0.098^{*} \log$ (length)
\end{tabular}

Non-parametric methods (Rank correlation after Spearman and after Kendall)

Temperature Mean length

Spearman: +0.799

Spearman: -0.31

$\mathrm{P}=0.01 \%$

$\mathrm{P}=0.11 \%$

Kendall: +0.588

Kendall: -0.215

$\mathrm{P}=0.01 \%$

$\mathrm{P}=0.08 \%$

instance the ${ }^{14} \mathrm{C}$-method after Steeman Nielsen (1952) or the ${ }^{15} \mathrm{~N}$-method for the determination of new production (Eppley, 1989). This is not true in the case of zooplankton. Methods in use are the determination of food uptake (for instance gut clearance method) or the determination of the amount of faecal material produced. The method used in our experiments was described first by Martens (1986). It determines the oxygen uptake of a zooplankton community in its natural composition (limited by the mesh size of the nets used). There are several other comparable methods in use, for instance those described by Richman (1958) or Comita (1968), measuring in closed systems and determining the oxygen content by means of the Winkler-method. Using polarographic oxygen sensors, as Ikeda (1977a) did, adds the advantage of a continuous recording of the oxygen content.

When sampling the zooplankton without sorting out single specimens, a great amount of phytoplankton will always be incubated in the experiments. Phytoplankton (as well as microbes) use oxygen in the dark. The method of Martens (1986) minimizes this problem by a subtraction method. In addition, sorting out single specimens always means stress to the animals. This leads to an effect reported by Ikeda (1977a) of a rapid decrease in oxygen occurring during the first hours of the experiment. This never happened during our experiments. Another factor which causes stress to the zooplankter could be the high numbers of animals in the incubation bottles. As found by Ikeda (1977b), concentrations of up to 23000 animals $1^{-1}$ (Acartia sp.) did not change the respiration rate significantly concentrations which were never reached during our experiments.

Starvation is another factor which influences the oxygen uptake of zooplankton. Ikeda (1977b), Mayzaud (1976), Skjoldal et al. (1984), Porter et al. (1982) and Vidal (1980) report of the negative influence of starvation on the respiration rate of zooplankton. There was always a great amount of phytoplankton or protozoans available during our experiments; the rate of oxygen depletion in the incubation bottles being nearly linear during all experiments. Considering the different methods used by various authors measuring the respiration of zooplankton in different parts of the world ocean with totally different 
zooplankton communities, one would expect a very great variation in the results. This is, however, not the case. Ivleva (1980) gives a review of respiration measurements with crustaceans. The weight-specific respiration rates are not significantly different from those given here. The same holds true for Rakusa-Suszczewski \& Opalinski (1978), Lampitt \& Gamble (1982), Ikeda (1970) or Conover (1960) who give nearly identical results (within the range of accuracy) for the respiration per dry weight of comparable species. So none of the methods used seems to give artificial results as long as care is taken to avoid stress to the animals.

The influence of temperature and size of the zooplankter has been described earlier. Vidal (1980) found an increasing metabolic level with increasing temperature. The amount of food available was of no importance (as long as starvation is avoided), as was found during our experiments).

Ikeda (1970) (and various other authors) report of decreasing weight-specific respiration rates with increasing size of the animals, as has been shown in our experiments.

Somehow astonishing was the fact that no great differences could be observed in the community respiration of the five drifting stations of our cruise. When the metabolic level decreased, the amount of zooplankton increased. This leads to a community respiration which has been reported earlier by Schneider et al. (1991) for the Red Sea and the Gulf of Aden with nearly identical values of 50 to $100 \mu \mathrm{g} \mathrm{O}_{2} \mathrm{~h}^{-1} \mathrm{~m}^{-3}$.

If one transforms these values to carbon assimilated (which only gives a very rough estimate) and compares it to phytoplankton standing stock carbon (which is also a very rough estimate), one can at least see that the mesozooplankton is seldom important in terms of the proportion of photosynthetically fixed carbon that it ingests. If one takes the primary production values during the JGOFS pilot study as a basis for the comparison of zooplankton grazing and phytoplankton, the relation is somewhat different (Lenz et al., 1992). This is due to very low primary production values measured during Meteor Cruise 10 which give a relation of phytoplankton standing stock to primary production of $100: 12$ (Lenz et al., 1992). The reason for these low primary production measurements are not known.

The low grazing pressure of the mesozooplankton on the phytoplankton population may be a seasonal effect. Thiel et al. (1989) report green material of phytoplankton origin at a depth of $4500 \mathrm{~m}$ in the northeast Atlantic Ocean. They come to the conclusion that as much as $3 \%$ of the spring phytoplankton bloom sinks as deep as $4500 \mathrm{~m}$. Similar effects were observed in the Kiel Bight (von Bodungen, pers. comm.) where the phytoplankton spring bloom could be found as a thick green layer on the seabottom. The aim of the next experiments planned on this problem must not be to analyse variation in space (there was nearly no variation in the community respiration from the equator to the Greenland Basin) but to analyse variation in time, to plan cruises in different seasons when the influence of the zooplankton on the turnover processes might be different.

Acknowledgements. I want to thank the captain and the crew of R.V. Meteor for their very good technical support during the long cruise, and C. Reineke for her expert technical assistance during the experiments. 


\section{LITERATURE CITED}

Bowles, M. C., 1991. JGOFS reviews its progress: Highlights of the bloom symposium. - U.S. JGOFS News, 2(3), 1-9.

Comita, G. W., 1968. Oxygen consumption in Diaptomus - Limnol. Oceanogr. 13, 51-57.

Conover, R. J., 1960. The feeding behaviour and respiration of some marine planktonic crustacea. Biol. Bull. mar. biol. Lab. Woods Hole 119, 399-415.

Eppley, R. W., Carlucci, A. F., Hansen, O. H., Kiefer, D., McCarthy, J. J., Venrick E. \& Williams P. M., 1973. A study of plankton dynamics and nutrient cycling in the central gyre of the North Pacific Ocean. - Limnol. Oceanogr. 18, 543-551.

Eppley, R. W., 1989. New production: history, methods, problems. In: Productivity of the ocean: present and past. Ed. by W. H. Berger, V. S. Smetacek \& G. Wefer. Wiley, New York, 85-97.

Ikeda, T., 1970. Relationship between respiration rate and body size in marine plankton animals as a function of the temperature of habitat. - Bull. Fac. Fish., Hokkaido Univ. 21, 91-112.

Ikeda, T., 1977a. The effect of laboratory conditions on the extrapolation of experimental measurements to the ecology of marine zooplankton. II. Effect of oxygen saturation on the respiration rate. - Bull. Plankt. Soc. Japan, 24, 19-28.

Ikeda, T., 1977b. The effect of laboratory conditions on the extrapolation of experimental measurements to the ecology of marine zooplankton. III. Short-term changes in the respiration rates of two subtropical zooplankton species. Acartia tonsa and Sagitta hispida. - Bull. Plankt. Soc. Japan, 24, 29-35.

Ivleva, I. V., 1980. The dependence of crustacean respiration rate on body mass and habitat temperature. - Int. Revue ges. Hydrobiol. 65, 1-47.

JGOFS, 1990. Science Plan. - JGOFS Rep. 5, 1-61.

Lampitt, R. S. \& Gamble, J. C., 1982. Diet and respiration of the small planktonic marine copepod Oithona nana. - Mar. Biol. 66, 185-190.

Lenz, J., Morales, A. \& Gunkel, J., 1992. Mesozooplankton standing stock during the North Atlantic spring bloom study in 1989: A comparison between low, medium and high latitudes. - Deep Sea Res. (In press.).

Martens, P., 1986. Diurnal variation in the respiration rate of natural zooplankton communities in the North Sea. - Oebalia, 13, 203-219.

Mayzaud, P., 1976. Respiration and nitrogen excretion of zooplankton. IV. The influence of starvation on the metabolism and the biochemical composition of some species. - Mar. Biol. 37, 47-58.

Parsons, T. R., Takahashi, M. \& Hargrave, B., 1984. Biological oceanographic processes. Pergamon, Oxford, $330 \mathrm{pp}$.

Porter, K. G., Gerritsen, J. \& Orcutt, J. D., 1982. The effect of food concentration on swimming patterns, feeding behaviour, ingestion, assimilation and respiration by Daphnia. - Limnol. Oceanogr. 27, 935-949.

Rakusa-Suszczewski, S. \& Opalinski, K. W., 1978. Oxygen consumption in Euphausia superba. Polski Arch. Hydrobiol. 25(3), 633-641.

Richman, S., 1958. The transformation of energy by Daphnia pulex. - Ecol. Monogr. 28, 273-291.

Robinson, A. R., McGillicuddy, D. J., Calman, J., Ducklow, H. W., Fasham, M. J. R., Hoge, F. E., Leslie, W. G., McCarthy, J. J., Podewski, S., Porter, D. L., Saure, G. \& Yoder, J. A., 1992. Mesoscale and upper ocean variabilities during the 1989 JGOFS Bloom Study. - Deep Sea Res. (In press.).

Saure, G. \& Podewski, S., 1990. Hydrographical observations during 5 drift experiments in investigation areas between $18^{\circ} \mathrm{N}$ and $72^{\circ} \mathrm{N}$ on Meteor 10/1-3. - Poster presented at JGOFS-Meeting Washington, November 1990. - JGOFS Rep. 7, Abstract.

Schneider, G., Lenz J. \& Rolke, M., 1991. Zum Bestand und Stoffumsatz des Ultra-, Mikro- und Mesoplanktons im Roten Meer und im Golf von Aden. - Ber. Inst. Meeresk. Kiel 205, 1-167.

Steemann Nielsen, E., 1952. The use of radio-active ${ }^{14} \mathrm{C}$ for measuring organic production in the sea. - J. Cons. perm. int. Explor. Mer 18, 117-140.

Skjoldal, H., Båmstedt, U., Klinken, J. \& Laing, A., 1984. Changes with time after capture in the metabolic activity of the carnivorous copepod Euchaeta norvegica Boeck. - J. exp. mar. Biol. Ecol. 83, 195-210.

STSC, 1987. STATGRAPHICS, Statistical graphics systems. STSC Inc., Rockville, 743 pp. 
Thiel, H., Pfannkuche, O., Schriever, G., Lochte, K., Gooday, A. J., Hemleben, C., Mantoura, R. F. G., Turley, C. M., Patching J. W. \& Riemann, F., 1989. Phytodetritus on the deep-sea floor in a central oceanic region off the Northeast Atlantic. - Biol. Oceanogr. 34, 203-239.

Vidal, J., 1980. Physioecology of zooplankton. III. Effects of phytoplankton concentration, temperature, and body size on the metabolic rate of Calanus pacificus. - Mar. Biol. 56, 195-202. 